Table 8. Treatment of the data of acid-resistance

$\begin{array}{cccccccccccccc} & \mathrm{B}_{2} \mathrm{O}_{3} & \mathrm{~K}_{2} \mathrm{O} & \mathrm{PbO} & \mathrm{TiO}_{2} & \mathrm{ZnO} & \mathrm{Al}_{2} \mathrm{O}_{3} & \mathrm{Li}_{2} \mathrm{O} & - & - & \text { Alkali } & \mathrm{MgO} & \mathrm{CaO} & \mathrm{BaO} \\ \text { Row No. } & 1 & 2 & 3 & 4 & 5 & 6 & 7 & 8 & 9 & 10 & 11 & 12 & 13 \\ \Sigma_{1} & 30 & 23 & 28 & 26 & 29 & 26 & 24 & 23 & 26 & 31 & 30 & 29 & 25 \\ \Sigma_{2} & 29 & 21 & 27 & 29 & 27 & 26 & 27 & 27 & 22 & 22 & 25 & 25 & 30 \\ \Sigma_{3} & 14 & 29 & 18 & 18 & 17 & 21 & 22 & 23 & 25 & 20 & 18 & 19 & 18\end{array}$

い. 最適焼成温度があまり高くならないようにして， しかも耐酸性を向上するためには，この列外を捉えて たとえば No.1 の組成に秝いて $\mathrm{Na}_{2} \mathrm{O}$ の $2 \%$ $\mathrm{SiO}_{2}$ で置き換えればよいと思われる。組成に対する加成性 のない性質を取扱う場合は，上記のような置換処理を いくつか実行してる, 期待通りの効果は得られないよ うである.すくなくとも No.1 ガラスよりは改善され ると云える程度であるう。

最後にこれと関連して耐酸粙組成の経済性について 言及しよう。熔融度が低くてしか子耐酸性のすぐれた 釉組成を合理的耐酸釉組成または最経済的耐酸橎組成 ということにすれば，との尺度は Tab. 6 亿示した雨 性質の等級の積によって与えることができる、高度の 耐酸性飞重点を置くならば，Vの列をもっと䈌しく， たとえば $0.20 \%$ を超えるものをすべて0につければ よいし, 最適焼成温度の低いことに重点を置くなら, III の列にもっと厳しく0を増せげよい. No. 1, 4, 5, 15 などが有能な組成であることがわかる。

\section{総括}

(1) 耐酸珪郳釉組成を対象とした多成分ガラスにつ いて組成置換を行ない, 各ガラスの 4,000 ポアズ附近 の粘度を測定することそよって, “最適焼成温度”の組 成に飞関する加成係数を導いた. 組成置換のやり方と
しては直交配列表 $L_{27}\left(3^{13}\right)$ 起利用し，バランスのと れた間引き置換を行なったが，加成性の認められる性 質を报う場合には十分罗当な結論を導きうることを示 した.

（2）この結果を利用して，いわゆる耐火係数を導出 した。これそより Danielson の耐火係数に招ける不 備な点, あるいは批判のあった点圭全面的に改善する ことができた。

(3) 組成江関する加成性の期待できない耐酸性なご の性質の直交表に和ける取扱いについて子考察し, 耐 酸釉組成の経済性について一つの尺度を与えた。

実験に協力された竹下友三君に謝意を表します。

\section{文献}

1) R.R. Danielson and Tetrick.Presented the Meeting of Am. Ceram. Soc., (1934)

2) 田代. 空協, 57 [642] 167 (1949)

3) 永井・井本. 珐瑯工業, 1 [4] 3 (1948)

4) S. English. J. Soc. Glass Technol., 9, 83 (1925); 10, 52 (1926)

5）田口. 実験計画法上 p. 49 (丸善 1957)

6) A.I. Andrews. Enamels, (Twin City Printing Co., 1935)

7) 田代. 案協, 57 [635] 30 (1949)

8）井本・平尾. 窯協, 67 [767] 381 (1959)

$(7 / 9 / 59$ 受付)

\title{
平炬に使用されたクロマグ煉瓦の $\mathrm{X}$ 線的研究
}

平炬飞使用された耐火物に関する研究（第 8 報）

\section{尾山竹滋 \\ (大阪大学産業科学研究所)}

\author{
Studies on the Refractories used in an Open-Hearth Furnace (VIII). \\ $\mathrm{X}$-ray Studies on the Chrome-Magnesia Bricks used in an Open-Hearth Furnace. \\ By Takeji OYAMA \\ (Inst. Sci. Ind. Res., Osaka Univ.)
}

\begin{abstract}
Microscopical and chemical studies on the mechanism of corrosion of chrome-magnesia refractories used in an open-hearth furnace were reported in previous papers, and the present one contains the results of X-ray studies on the constitutional minerals (spinel periclase and matrix minerals) in every zones of the burned chrome-magnesia brick from the front wall and the unburned brick from the zebra roof of basic open-hearth furnace.
\end{abstract}


The lattice constants of original chromite spinel separated from the lowest temperature (unaltered) zone, magnetite spinel in the working face of the burned brick and that embeded in a silicious glass matrix in the unburned brick from zebra roof were $8.21,8.35$ and $8.40 \AA$ respectively. This expansion of the spinel due to the variation of its chemical composition is connected with the bursting phenomenon of the brick.

Augite is a predominant constitutional mineral of matrix in the hottest face, and forsterite and monticellite are principal matrix minerals in the middle zone of the brick.

\section{緒言}

製銅用平梳使用されたクロマグ系而火物の侵蝕機 構についての鉱物学的括よび化学的研究結果について はすで報告した ${ }^{1-4)}$ 。本報ではこのようなクロマグ

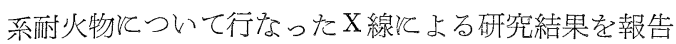
する。すなわ台平炉の前壁隹用いられた焼成型煉瓦 と, ゼブラ式天井拥いられた不焼成型煉瓦と飞つい て広義のスピネル鉱物とペりクレスとマトリックス鉱 物とに分けてX線回折計数装置により回折図形を作製 し, その格子定数を求め, あるいはマトリックス鉱物 そついての同定結果とついて以下に詳述する。

\section{I. 試 料 棟 瓦}

焼成型クロマグ煉瓦恬 40 トン塩基性平炉の前壁に 114 回使用後のもので, その断面の色の変化飞より高 温端から A,B,C,Dの4 層飞分子た。 その顕微鏡観察 と化学組成の変化とについては，平炉耐火物関する 第 3 報 ${ }^{1}$ 和よび第 4 報 $^{2}$ 飞詳述したところである。

不焼成型煉瓦は，いわゆるゼブラ式天井で珪石煉瓦 と隣接して 402 回使用後の8ので高温端から A,B,C,

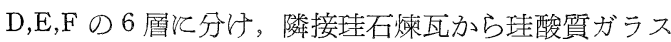
の侵入している部分を $\mathrm{G}$ 層と名付けた。その詳細は同 前第 6 報引飞述べたから重複をさけ省略する。

\section{II. スピネル部について}

a）焼成型クロマグ燌瓦重传法によって分離し たスピネル部（此重 3.50 以上の部分）についてX線 粉末回折図形を作りその格子定数を求めた。 条件は, レルコX 線回折装置を使用しコバルト対㓌極を用い $25 \mathrm{kV} ; 10 \mathrm{~mA}$, Scale factor 4, Multiplier 1, Time constant 4 秒, Scanning speed 毎分 $1^{\circ}$ で行なった。 回折線の位置怟温部 (D層) 加䯩温部 ( $\mathrm{A}$ 層) へ行 く筀って回折角の小さい方へ移動している。Table 1 亿回折線の位置，相対強度，指数，格子定数の実測 值, 計算值を示す。計算值はこれらの化学組成 ${ }^{3)}(\mathrm{Ta}$ ble 2) 加求め鉱物組成計算值 ${ }^{3}$ 加 V Vegard の法 則 ${ }^{51}$ とって算出したbので Table 3 とスピネル（狭 義）とマグネタイトとのモル百分率を示す。計算以用 いたスピネル端分子の格子定数はVerwey ( $^{6}$ 飞よっ た. その他の文献值と共飞 Table 4 飞示す。計算值 が実測值より常と少し小さくなっているのは鉱物組成 の計算の仮定 ${ }^{3}$ の不䚚による多のであるう。測定值か
Table 1. X-ray powder data of spinel solid solution in the burned chrome-magnesia brick used in the front wall of an open hearth furnace. (Co. $K_{\alpha}, 25 \mathrm{kV}, 10 \mathrm{~mA}, 4-1-4$, $1^{\circ} / \mathrm{min}$.)

\begin{tabular}{ccccccc}
$\theta$ & $I$ & $d(\AA)$ & $\sin \theta$ & hkỉ & & $a(\AA)$ \\
A-zone(Hottest & surface) & & & & \\
10.70 & 0.27 & 4.818 & 0.1856 & 111 & & 8.345 \\
17.65 & 0.50 & 2.950 & 0.3032 & 220 & & 8.344 \\
20.85 & 1.00 & 2.513 & 0.3559 & 311 & & 8.334 \\
25.35 & 0.26 & 2.082 & 0.4282 & 400 & & 8.356 \\
31.75 & 0.15 & 1.714 & 0.5262 & 422 & & 8.398 \\
33.95 & 0.25 & 1.602 & 0.5585 & 511,333 & & 8.324 \\
37.40 & 0.38 & 1.473 & 0.6074 & 440 & & 8.332 \\
& & & & & mean & 8.347 \\
B-zone & & & & & calc. & 8.32 \\
10.85 & 0.78 & 4.752 & 0.1882 & 111 & & 8.231 \\
17.95 & 0.36 & 2.902 & 0.3082 & 220 & & 8.208 \\
21.15 & 1.00 & 2.479 & 0.3608 & 311 & & 8.222 \\
25.80 & 0.67 & 2.055 & 0.4352 & 400 & & 8.220 \\
34.43 & 0.45 & 1.582 & 0.5654 & 511,333 & & 8.220 \\
38.00 & 0.67 & 1.453 & 0.6156 & 440 & & 8.222 \\
\multicolumn{7}{c}{} \\
& & & & mean & 8.220 \\
D-zone (Cold end) & & & & calc. & 8.20 \\
10.90 & 0.68 & 4.730 & 0.1891 & 111 & & 8.193 \\
17.88 & 0.35 & 2.913 & 0.3071 & 220 & & 8.239 \\
21.20 & 1.00 & 2.473 & 0.3616 & 311 & & 8.202 \\
25.85 & 0.36 & 2.051 & 0.4360 & 400 & & 8.206 \\
34.45 & 0.36 & 1.581 & 0.5657 & 511,333 & & 8.215 \\
38.00 & 0.49 & 1.453 & 0.6156 & 400 & & 8.218 \\
& & & & & mean & 8.212 \\
& & & & & calc. & 8.20
\end{tabular}

Table 2. Chemical composition of the spinels separated from the burned chrome-magnesia brick used in an open-hearth furnace. (Wt.\%)

\begin{tabular}{lrrr} 
Zone & \multicolumn{1}{c}{ A } & \multicolumn{1}{c}{ B } & \multicolumn{1}{c}{ D } \\
$\mathrm{Al}_{2} \mathrm{O}_{3}$ & 3.46 & 27.79 & 26.85 \\
$\mathrm{Cr}_{2} \mathrm{O}_{3}$ & 29.85 & 31.52 & 33.45 \\
$\mathrm{Fe}_{2} \mathrm{O}_{3}$ & 44.26 & 15.37 & 13.05 \\
$\mathrm{FeO}$ & 9.19 & 2.24 & 1.42 \\
$\mathrm{MnO}$ & 0.95 & 0.17 & 0.22 \\
$\mathrm{MgO}$ & 12.29 & 22.91 & 25.01 \\
Total & 100.00 & 100.00 & 100.00
\end{tabular}

Table 3. Spinel : Magnetite ratio in the spinel solid solution of the burned chrome-magnesia brick (Mol.\%).

$\begin{array}{cccc}\text { Spinel }(\mathrm{Mg}, \mathrm{Fe}, \mathrm{Mn})(\mathrm{Al}, \mathrm{Cr})_{2} \mathrm{O}_{4} & 51 & \mathrm{~B} & \mathrm{D} \\ \text { Magnetite }(\mathrm{Mg}, \mathrm{Fe}, \mathrm{Mn}) \mathrm{Fe}_{2} \mathrm{O}_{4} & 49 & 17 & 14\end{array}$

ら各層のスピネル固溶体の容積比学求めると, D層の ものを標準とすればB層では $0.3 \%$ ，A層では $5 \%$ の 膨脹となる。このような膨脹は格子の大きいマグネタ イトを多量に固溶したことによるものである。

回折線の形はD首のものはシャープであるがB層か 


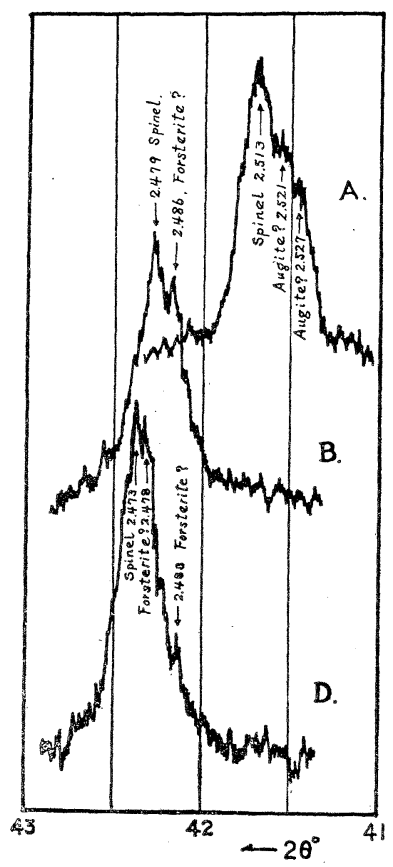

Fig.1. X-ray diffraction powder patterns of 311 reflection of the spinels removed from each zone in the burned chrome-magnesia brick, showing the shifts of peaks and broadening of the lines. (Co. $K_{\alpha}$, $25 \mathrm{kV}, 10 \mathrm{~mA}, 4-1-4,1^{\circ} / 4 / \mathrm{min}$.)

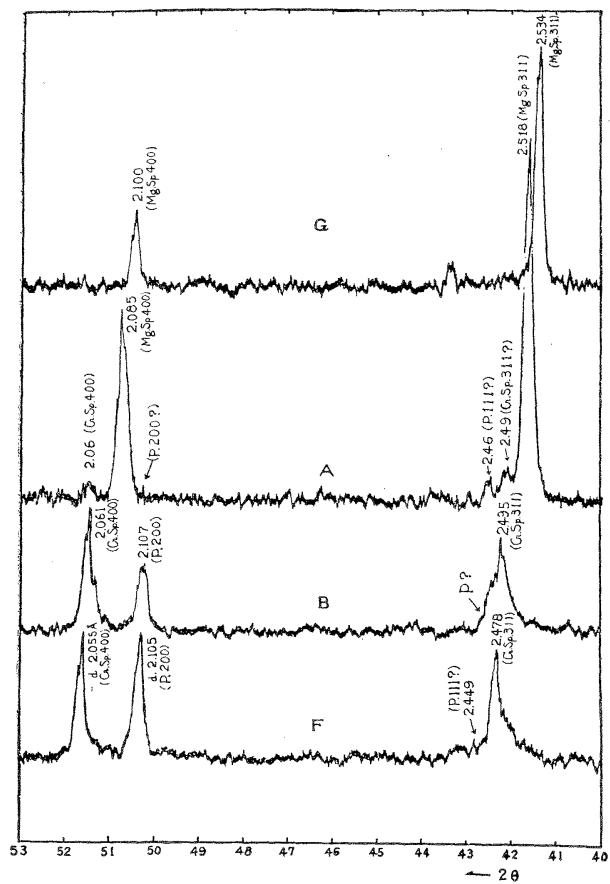

Fig.2. X-ray diffraction patterns of the spinels in each zone of the unburned chrome-magnesia brick from a zebra roof. Mg.Sp. : Magnetite spinel, Cr.Sp. : Chrome spinel, P. : Periclase. (Co. $K_{\alpha}, 25 \mathrm{kV}, 10 \mathrm{~mA}, 4-1-4$, Scanning speed $1^{\circ} / 2 / \mathrm{min}$.)
らA層へと高温になるに従ってブロードになり，四 先端も乱れる傾向を有することが知られたので各回折 線について，他の条件はそのまをで Scanning speed のみを毎分 $1 / 4^{\circ}$ 亿落して曲線を描かした．指数 311 の一例を Fig. 1 亿示す。このような回折線の乱机に ついては第一に本試料では分離が不完全で少量のマト リックス珪酸塩鉱物を共存していてそれらの回折線と の重なりであると考觉られる。Fig.1 で見られるよう 飞D 層の曲線の $d=2.478,2.488 \AA$ のるの，特よび B首の $2.486 \AA$ ものはいずれもフォルステライトのそ れではないかと思われ，また $\mathrm{A}$ 層の 2.521 と $2.527 \AA$ のものは煇石の回折線に相当するものがあることは後 述する各該当層の分離マトリックスの図形 (Fig. 3,4)

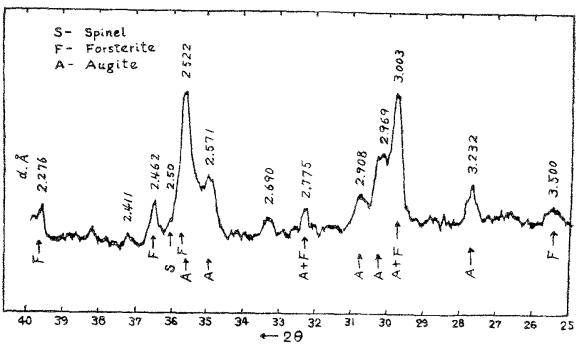

Fig.3. X-ray diffraction powder pattern of the matrix minerals taken from A-zone (Hottest surface) in the burned chromemagnesia brick. S : Spinel remained, A :Augite, F : Forsterite. (Cu. $K_{\alpha}, 30 \mathrm{kV}$, $15 \mathrm{~mA}$, Time const. $10 \mathrm{sec}$. Scanning speed $1^{\circ} / 4 / \mathrm{min}$.)
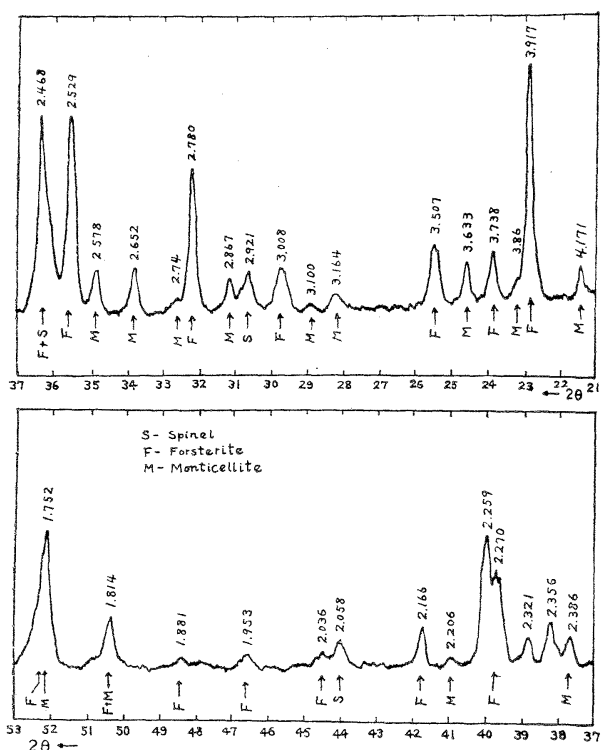

Fig. 4 X-ray diffraction powder pattern of the matrix minerals taken from B-zone in the burned chrome-magnesia brick. S : Spinel remained, $F$ : Forsterite, $M$ : Monticellite. (Cu. $K_{\alpha}, 30$ $\mathrm{kV}, 15 \mathrm{~mA}$, Time const. $10 \mathrm{sec}$. Scanning. speed $1 \% / 2 /$ min.) 
を見れば明らかである。しかしまた第二にこれらの回 折線が高温部のもの程ブロードとなっていることをも 併世考觉れば必らずしも他の鉱物との重なりのみとは 考光られない，この点については例党ば Winchel1 ${ }^{91}$ はスピネル (狭義) はマグネタイトの浪ぼ 15\% 以上 を固溶するととは出来ないから，岩漿が冷却すればス ピネルとマグネタイトとは別々と晶出すると結論して いることは，ちょうどそのままこの現象に適用するこ とが出来るであろう、すなわち, 本試料は Table 3 で 明らかなよう飞高温端では多量の酸化鉄を含有してい る. 平炉で使用中の高温度では幾つかのスピネル端分

Table 4. Lattice constants of pure spinels. (A)

$\begin{array}{lccc}\quad \text { Spinel } & 1 & 2 & 3 \\ \mathrm{MgO} \cdot \mathrm{Al}_{2} \mathrm{O}_{3} & 8.07 & 8.086 & 8.086 \\ \mathrm{FeO} \cdot \mathrm{Al}_{2} \mathrm{O}_{3} & 8.12 & 8.119 & \\ \mathrm{MnO} \cdot \mathrm{Al}_{2} \mathrm{O}_{3} & 8.26 & 8.271 & \\ \mathrm{MgO} \cdot \mathrm{Cr}_{2} \mathrm{O}_{3} & 8.31 & 8.305 & 8.308 \\ \mathrm{FeO} \cdot \mathrm{Cr}_{2} \mathrm{O}_{3} & 8.34 & 8.344 & \\ \mathrm{MnO} \cdot \mathrm{Cr}_{2} \mathrm{O}_{3} & 8.49 & 8.436 & \\ \mathrm{MgO} \cdot \mathrm{Fe}_{2} \mathrm{O}_{3} & 8.36 & 8.366 & 8.366 \\ \mathrm{FeO} \cdot \mathrm{Fe}_{2} \mathrm{O}_{3} & 8.39 & 8.374 & 8.374 \\ \mathrm{MnO} \cdot \mathrm{Fe}_{2} \mathrm{O}_{3} & 8.55 & 8.457 & \\ \text { Reference } & 6 & 7 & 8\end{array}$

Table 5. X-ray powder data of spinel solid solution of the unburned chrome-magnesia brick used in the zebra roof of an open-hearth furnace. (Co. $K_{\alpha}, 25 \mathrm{kV}, 10 \mathrm{~mA}, 4-1-4$, $1^{\circ} / 2 /$ min.)

\begin{tabular}{|c|c|c|c|c|c|c|}
\hline$\theta$ & $I$ & $d(\AA)$ & $\sin \theta$ & hkl & & $a(\AA)$ \\
\hline \multicolumn{7}{|c|}{ G-zone (Hottest surface with glass matrix) } \\
\hline 10.63 & 0.29 & 4.8489 & 0.1845 & 111 & & 8.398 \\
\hline 17.54 & 0.39 & 2.9679 & 0.3013 & 220 & & 8.394 \\
\hline 20.67 & 1.00 & 2.5340 & 0.3529 & 311 & & 8.404 \\
\hline .25 .21 & 0.36 & 2.1000 & 0.4258 & 400 & & 8.400 \\
\hline 31.47 & 0.11 & 1.7133 & 0.5220 & 422 & & 8.393 \\
\hline 33.60 & 0.26 & 1.6163 & 0.5534 & 511,333 & & 8.398 \\
\hline \multirow[t]{3}{*}{37.05} & 0.39 & 1.4845 & 0.6025 & 440 & & 8.397 \\
\hline & & & & & mean & 8.398 \\
\hline & & & & & calc. & 8.38 \\
\hline \multicolumn{7}{|c|}{ A-zone(Hottest surface) } \\
\hline 10.70 & 0.14 & 4.8175 & 0.1856 & 111 & & 8.344 \\
\hline 17.64 & 0.57 & 2.9516 & 0.3029 & 220 & & 8.348 \\
\hline 20.81 & 1.00 & 2.5177 & 0.3551 & 311 & & 8.350 \\
\hline 25.40 & 0.52 & 2.0853 & 0.4289 & 400 & & 8.341 \\
\hline 31.68 & 0.09 & 1.7031 & 0.5252 & 422 & & 8.343 \\
\hline \multirow[t]{3}{*}{33.82} & 0.31 & 1.6070 & 0.5565 & 511,333 & & 8.350 \\
\hline & & & & & mean & 8.346 \\
\hline & & & & & calc. & 8.33 \\
\hline \multicolumn{7}{|l|}{ B-zone } \\
\hline 10.80 & 0.42 & 4.7734 & 0.1874 & 111 & & 8.267 \\
\hline 17.85 & 0.28 & 2.9180 & 0.3065 & 220 & & 8.253 \\
\hline 21.10 & 0.76 & 2.4946 & 0.3600 & 311 & & 8.273 \\
\hline \multirow[t]{3}{*}{25.72} & 1.00 & 2.0611 & 0.4339 & 400 & & 8.244 \\
\hline & & & & & mean & 8.258 \\
\hline & & & & & calc. & 8.25 \\
\hline \multicolumn{7}{|c|}{ F-zone (Cold end) } \\
\hline 10.88 & 0.47 & 4.7387 & 0.1888 & 111 & & 8.207 \\
\hline 17.93 & 0.24 & 2.9054 & 0.3079 & 220 & & 8.217 \\
\hline 21.16 & 0.87 & 2.4779 & 0.3611 & 311 & & 8.218 \\
\hline 25.80 & 1.00 & 2.0551 & 0.4352 & 400 & & 8.220 \\
\hline 32.22 & 0.13 & 1.6776 & 0.5331 & 422 & & 8.218 \\
\hline 34.44 & 0.31 & 1.5816 & 0.5654 & 511,333 & & 8.218 \\
\hline \multirow[t]{3}{*}{38.05} & 0.40 & 1.4512 & 0.6163 & 440 & & 8.209 \\
\hline & & & & & mean & 8.215 \\
\hline & & & & & cal & 8.25 \\
\hline
\end{tabular}

子組成は完全飞固溶し, 温度の降下と共飞分離析出し ようとしたが煉瓦の表面首は比較的急速に温度が降下 したとすれば当然分離は不完全となり，このような結 晶中には多くの格子不整が生ずるであろう，従って本 試料のA層中のスピネル鈗物の回折線のピークの乱 れ, 特よび幅の拡がりは分離析出初期の格子不整によ ると考觉られる。

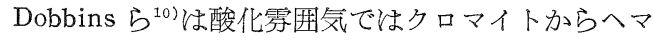
タイトの分離を報告しているが，本試験ではその痕跡 は認められるが強度が弱く充分確認できなかった。

b）不焼成型クロマグ煤瓦 前述したゼブラ天井 で珪石煉瓦と隣接して使用された試料眯瓦について, レルコX線回折装置によって得られたデー夕をTable 5 飞示す. 本試料の $\mathrm{A}$ 層のスピネル鉱物の格子定数の 笑測值は前述した焼成型の $\mathrm{A}$ 層のものと汪とえぞ同じ で元のクロマイトル比して約 $5 \%$ の容積増加を示して いるが，G層のものはな扔一首膨大となり約 $7 \%$ の膨 脹を示している。これはその化学分析值 ${ }^{3)}$ (Table 6) とそ水からの鉱物組成の計算值 ${ }^{3}$ (Table 7 ) から知ら れるよう飞 $\mathrm{G}$ 招よび $\mathrm{A}$ 層ではマグネタイトが激增し， 特飞 $\mathrm{G}$ 層で恪アルミナ，マグネシアが減少しているた めで，この上うな耐火物の主成分であるスピネル鉱物 の結晶格子の膨脹は煉瓦を崩壊へ導くであるう。

Table 6. Chemical composition of the spinels separated from the unburned chrome-magnesia brick used in a zebra roof. (Wt. $\%$ )

\begin{tabular}{lrrrr} 
Zone & G & \multicolumn{1}{c}{$\mathrm{A}$} & \multicolumn{1}{c}{$\mathrm{B}$} & \multicolumn{1}{c}{$\mathrm{F}$} \\
$\mathrm{Al}_{2} \mathrm{O}_{3}$ & 0 & 5.5 & 16.4 & 18.5 \\
$\mathrm{Cr}_{2} \mathrm{O}_{3}$ & 39.2 & 11.4 & 28.3 & 41.0 \\
$\mathrm{Fe}_{2} \mathrm{O}_{3}$ & 45.0 & 58.1 & 18.3 & 13.6 \\
$\mathrm{FeO}$ & 11.4 & 13.1 & 3.9 & 5.4 \\
$\mathrm{MgO}$ & 4.2 & 11.8 & 31.8 & 19.7 \\
$\mathrm{MnO}$ & 0.2 & 0.1 & 1.3 & 1.8 \\
Total & 100.0 & 100.0 & 100.0 & 100.0
\end{tabular}

Table 7. Spinel : Magnetite ratio in the spinel solid solutions of the unburned chromemagnesia brick (Mol.\%).

Zone G A $B$ B Spinel $(\mathrm{Mg}, \mathrm{Fe}, \mathrm{Mn})(\mathrm{Al}, \mathrm{Cr})_{2} \mathrm{O}_{4} \quad 35 \quad 27 \quad 78 \quad 88$ Magnetite $(\mathrm{Mg}, \mathrm{Fe}, \mathrm{Mn}) \mathrm{Fe}_{2} \mathrm{O}_{4} \quad \begin{array}{lllll}65 & 73 & 22 & 12\end{array}$

回折線の形状については Fig. 2 飞示すようと焼成 型と甜けるとは少しく異なり，中間層で一度ブロード そなり高温端でシャープそなっている．特にA層では 図湖らかなように $d=2.085,2.518 \AA$ の強いピーク はマグネタイト質スピネルの回折線であるが，いずれ も气机上り少し回折角の大きい方飞 $(d=2.06,2.46$ 委 たは $2.49 \AA)$ 弱いピークが見られる。これは B, F 層 のクロマイトの指数 400,311 の線に汴ぼ一致する。こ れらのことを前述しを焼成型試料と比較検討するに Table 3,7 で知られるようとスピネル間の固溶飞関連 するすのと思われる。すなわらアルミナスピネルとク ロムスピネル間，またはマグネタイトスピネル相互間 ではいずれもとれぞれの端分子は完全固溶体を作る 
が, 前者と後者との間では固溶限が存在し, 従って徐 冷によって分離晶出するが急冷すれば分離は不完全と なり，格子不整の多いブロードな回折線を与えるであ ろう。それ故的 $\mathrm{G}, \mathrm{A}$ 層で多量のマグネタイトル少 量のクロムスピネルをたはアルミナスピネルが溶解 乙， B,F 層ではクロムスピネルが主成分で少量のマグ ネタイトを固溶している状態であり，特にB層ではマ グネタイトの固溶限界附近であったので泠却により分 離の傾向を示しブロードな回折線となったと考えられ る.

\section{III. ペリクレスについて}

焼成型試料のA層では顕微鏡下では不明であったが X 線試験では検出された。得られた結果をTable 8 そ 示す。格子定数は文 献 值 ${ }^{11)}(4.203 \AA)$ とほぼ一致す るが中間層で少し大きくなる傾向が認められる。

Table 8. X-ray powder data of periclase in the burned chrome-magnesia brick. (Co. $\mathrm{K}_{\alpha}$, $25 \mathrm{kV}, 10 \mathrm{~mA}, 4-1-4,1^{\circ} / \mathrm{min}$.)

\begin{tabular}{|c|c|c|c|c|c|c|}
\hline$\theta$ & $I$ & $d(\AA)$ & $\sin \theta$ & hkl & & $a(\AA)$ \\
\hline \multicolumn{7}{|c|}{ A-zone(Hottestsurface) } \\
\hline 25.28 & 0.7 & 2.095 & 0.4268 & 200 & & 4.189 \\
\hline 37.12 & 1.0 & 1.482 & 0.6034 & 220 & & 4.192 \\
\hline \multirow[t]{2}{*}{47.58} & 0.5 & 1.212 & 0.7383 & 222 & & 4.197 \\
\hline & & & & & mean & 4.193 \\
\hline \multicolumn{7}{|l|}{ B-zone } \\
\hline 25.20 & - & 2.101 & 0.4258 & 200 & & 4.201 \\
\hline \multicolumn{7}{|c|}{ D-zone(Cold end) } \\
\hline 21.68 & 0.3 & 2.421 & 0.3695 & 111 & & 4.194 \\
\hline 25.25 & 1.0 & 2.097 & 0.4266 & 200 & & 4.194 \\
\hline \multirow[t]{2}{*}{37.07} & 0.5 & 1.484 & 0.6027 & 220 & & 4.197 \\
\hline & & & & & mean & 4.195 \\
\hline
\end{tabular}

不烍成型武料では $\mathrm{G}$ 層および $\mathrm{A}$ 屏では認められず, B 層で指数 200 のもの゙明瞭飞認められたが Fig.2 で見られるようとその尖端は乱れている。これは $\mathrm{MgO}$ ・ $\mathrm{FeO}$ 亲たは $\mathrm{MgO} \cdot \mathrm{Fe}_{2} \mathrm{O}_{3}$ を含むためと考方られ， $\mathrm{F}$ 層の子の純粋に近いために回折線す強くシャープで ある. 得られた結果は Table 9 飞示す。格子定数の $4.21 \AA$ 文献值と浪とえど一致した。

Table 9. X-ray powder data of periclase in the unburned chrome-magnesia brick. (Co. $K_{\alpha}, 25 \mathrm{kV}, 10 \mathrm{~mA}, 4-1-4,1^{\circ} / 2 / \mathrm{min}$.)

\begin{tabular}{|c|c|c|c|c|c|}
\hline$\theta$ & $I$ & $d(\AA)$ & $\sin \theta$ & hk1 & $a(\AA)$ \\
\hline \multicolumn{6}{|c|}{$\begin{array}{l}\text { G-zone (Hottest surface with glass matrix) } \\
\text { None }\end{array}$} \\
\hline \multicolumn{6}{|c|}{ A-zone (Hottest surface) } \\
\hline \multicolumn{6}{|l|}{ B-zone } \\
\hline 25.12 & & 2.1070 & 0.4244 & 200 & 4.214 \\
\hline \multicolumn{6}{|c|}{ F-zone(Cold end) } \\
\hline 21.42 & 0.17 & 2.4492 & 0.3651 & 111 & 4.242 \\
\hline 25.15 & 1.00 & 2.1046 & 0.4250 & 200 & 4.209 \\
\hline 36.92 & 0.27 & 1.4890 & 0.6006 & 220 & 4.211 \\
\hline
\end{tabular}

IV.マトリックス鉱物の同定

焼成型試料について重液分離物（比重 3.50 以下の 部分）について銅対陰極安用いてX線回折図形を作製
した、A首のものを Fig. 3 亿示す. 回折線の位置と 相対強度とから多量の輝石と少量のカンラン石とから 成ることを知った。殚石とカンラン石の同定出とれ登 れ Kuno ${ }^{(2)}$ 和よび Hanawalt ${ }^{13}$ 江よった。

B 尿のマトリックス鉱物についてはFig.4 飞示すよ うにカンラン石とモンチセライトとが主成分であるこ とを知った。モンチセライトの同定は Rait ${ }^{8)}$ とっ。 た、回折線が非常にシャープであることから良好な結 晶であることが知られるが，これは煉瓦の内部であっ

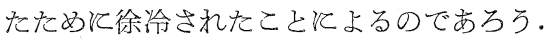

な招二，三の同定することが出来なかった回折線の 未知鉱物について产後の研究定進めたい。

\section{総括}

平桾に用いられたクロマグ煉瓦のX線試験の結果の 要点を列記すれば次のようである。

クロマイトは煉瓦の稼銜表面では多量の酸化鉄を溶 解してマグネタイト化し，との結果結晶格子は約 $5 \%$ 増大する。特にゼブラ天井に用いられて隣接した珪石 䍒瓦から侵入した珪酸質マトリックス中にあったるの ばそのスピネル組成中からアルミナスピネルが選択的 飞溶解抽出される結果，格子はな括一層大きくなり初 めのクロマイトに比し約 $7 \%$ の膨脹を示していた。

回折線の形状については各スピネル鉱物間の溶解限 と泠却速度と飞関連するものと考光られ，な和純粋の 端分子に関して今後の研究を必要とする。

各層のスピネル鉱物和よびペりクレスの格子定数は

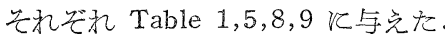

マトリックス鉱物については高温端では輝石が，低 温部ではカンラン石とモンチセライトとが主成分であ ることを知った。

後記，本研究用試料を恵与された大阪製鋼株式会社 高石社長ならびに研究飞御指導御助言を賜的った青研 究室主任教授, 本学理学部仁田, 渡辺教授, 桐山助教 授に心からの深謝の意を表す。

\section{文献}

1) 青, 尾山. 勲協, 63 [716] 629-33 (1955)

2) 青，尾山・弿協，64 [732] 282-87 (1956)

3）青，尾山。弿協, 66 [756] 286-94 (1958)

4) T. Oyama. Mem. Inst. Sci. Ind. Res., Osaka Univ., 16, 161-73 (1959)

5) L. Vegard. Zeit. Phys., 5, 393 (1921); K.R. Van Horn, A.S.T.M., Symposium on Radiography and X-ray Diffraction (1936); J.R. Rait. Basic Refractories, p.86 (1950)

6) E.J.W. Verwey, E.L. Heilman. J. Chem. Phys., 15, 174-80 (1947); 吉木文平。鉱物工学 (技報堂) p.508 (1959)

7) G.L. Clark, A. Alley, A.E. Badeger. Amer. J. Soc., 22 [5] 539-46 (1931); 吉术文平. 鉱 物工学 (技報堂) p.512 (1959) 
8) J.R. Rait. Basic Refractories, London (1950)

9) A.N. Winchell. Amer. Mineral., 26, 422 (1941)

10) N.E. Dobbins, W.J. Rees. Iron Steel Inst. Spec.Rep., 32, 211 (1946)

11) R.W.G. Wyckoff. Amer. J. Sci., 210, 107
(1925); A.N. Winchell, H. Winchell. Elements of Opt. Mioe. II, p.58 (1951)

12) H. Kuno. Amer. Mine., 40, 70-93 (1955)

13) J.D. Hanawalt, H.W. Rinn, L.K. Frevel. Ind. Eng. Chem., Anal. Ed., 10,457 (1938)

( $7 / 9 / 59$ 受付)

\title{
射出成形窒業品の焼成結果に及ぼす加熱姏理の影響
}

射出成形方法による筌業品の製造飞関する研究（第 2 報）

茂木朝雄

(日立製作所多賀工場穼業課)

\section{A Study on Various Factors in the Heating Treatment} of the Injection Molded Ceramic Articles

Studies on the Injection Molding of Ceramics, II.

By Asao MOTEKI

(Hitachi Seisakusho, Ltd.)

\begin{abstract}
The effects of several additions and heating velocities on the firing characteristics of the injection molding of ceramics were studied.

Stearic acid and D.E.P. added to polystyrene as the lubricant or the plastitizer gave favorable results for improving the plasticity of the mix. Particularly, D.E.P. showed the best heating properties which mainly come from its low volatilization temperature.

Taking into consideration the effect of stearic acid on the heating properties of molded ceramics it was confirmed that the amount should be kept less than $4 \%$.

As the heating velocity has remarkable influence on the heating properties the heating schedule should be determined by taking into concideration of the kind of agents, and the thickness of the article.

The molded articles of $6 \mathrm{~mm}$ thick $\left(\mathrm{Al}_{2} \mathrm{O}_{3}\right.$-styrene-stearic acid-D.E.P. system) must be heated with the velocities less than about $7^{\circ} \mathrm{C}$ per hour.
\end{abstract}

緒言

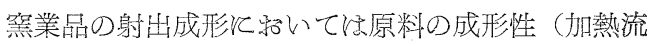
動性）之成形品の整成性状がもっとも重要である。従 って成形性を良好飞するため使用する䄈脂, 乞の他

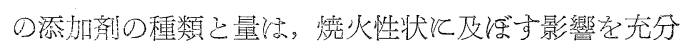

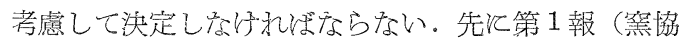
81 [12]450 (1959)) 飞新いて $\mathrm{Al}_{2} \mathrm{O}_{3}$ 素地飞対与るポ リスチレン,ステアリン酸, D.E.P. の成形性飞つい て検討し炕結果，ポリスチレン 14〜16\% ステアリン 酸 2〜4\%，D.E.P. 0 2\%の範囲内で良好孚成形性を 有与る射出宰業原料悬出してととを報告した。

一般飞射出成形案業品の㜔成中、生ずる変形, 発

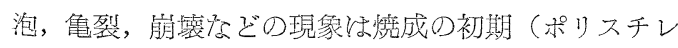
ンの分解温度以下）飞郝ける成形品の熱軟化性の回復

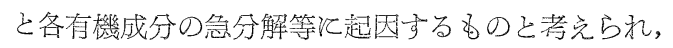

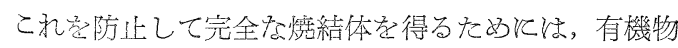
の分解を肪るゃ加に行なうための長時間低温加熱処理
のほか(1)有機成分の添加量を極力減少する。 (2)分解温

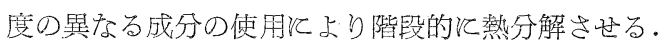
(3)便用する樹脂の一部季たは全部を燒成工程で熱硬化 性飞変觉る。(4)有機成分の分解消失を容易飞するため 飞原料粘度を考慮する。(5)減压加熱, 強制加熱など特 殊な加熱処理方法による。などの手段が考光られる。 この報告では特に各有機成分の熱分解特性について検 討し，乞の最良条件の配合組成による成形品の，加熱 速度による諸影響について実験を行なった結果につい て述べる。

\section{I. 射出成形窐業品を焼成した場合の 育機成分の影響に関する考察}

筧業原料江熱可塑性樹脂乞の他学混合した場合, 添 加量の増加飞伴なって熱流動性加增し成形性ほ向上す る. 乙かし成形品は本質的飞熱軟化性を有するため, これを焠固して筭業製品沉する加熱工程中，合有され 